\title{
Profil Pasien Eritroderma di Rumah Sakit Pertamina Bintang Amin Periode Januari 2016 - Desember 2019
}

\author{
Arif Effendi $^{1}$, Eka Silvia ${ }^{2}$, M. Syafei Hamzah ${ }^{3}$, M. Ridho Noverliansyah ${ }^{4}$ \\ Departemen Dermatologi \& Venereologi, Fakultas Kedokteran,Universitas Malahayati \\ arif.effendi62@gmail.com ${ }^{1}$ \\ Departemen Fisiologi, Fakultas Kedokteran,Universitas Malahayati \\ Bundaekas18@gmail.com ${ }^{2}$ \\ Departemen Dermatologi \& Venereologi, Fakultas Kedokteran, Universitas Malahayati \\ mazcosyaf@yahoo.com ${ }^{3}$ \\ Program Studi Kedokteran, Fakultas Kedokteran, Universitas Malahayati \\ lian.md96@gmail.com ${ }^{4}$
}

\begin{abstract}
ABSTRAK
Eritroderma merupakan inflamasi pada kulit yang mengenai 90\% atau lebih luas permukaan kulit, dan dapat disertai skuama. Beberapa laporan kasus didapatkan insidensi eritroderma pada pria lebih besar daripada wanita, dengan kasus 2:1 sampai 4:1, dan rata-rata pada usia 41-61 tahun. Terapi eritroderma harus disesuaikan dengan kondisi penyakit. Angka kematian tergantung pada penyebab terjadinya eritroderma. Dikarenakan belum banyaknya data penelitian mengenai eritroderma membuat peneliti ingin lebih mengetahui karakrakteristik dari penyakit tersebut. Penelitian Untuk Mengetahui profil pasien eritroderma di Rumah Sakit Pertamina Bintang amin termasuk insidensi, usia, jenis kelamin, faktor penyebab dan penatalaksanaanya. Penelitian menggunakan metode observasional deskriptif dengan desain retrospektif, sampling menggunakan total sampling. Hasil Penelitian didapatkan insidensi eritroderma tertinggi terjadi pada tahun 2016 sebanyak 11 orang (50,0\%). Mayoritas pasien eritroderma dengan jenis kelamin laki-laki sebanyak 13 orang (59,1\%). Pasien eritroderma dengan usia >60 tahun menempati posisi tertinggi sebanyak 14 orang (63,6\%). Faktor Penyebab eritroderma tertinggi ialah Perluasan penyakit sebanyak 11 orang (50,0\%). Penatalaksanaan paling banyak yang diberikan ialah kortikosteroid oral + pelembab + antihistamin sebanyak 12 orang (54,5\%). Kesimpulan Insidensi eritroderma tertinggi pada tahun 2016, Mayoritas pasien eritroderma dengan jenis kelamin laki-laki, Pasien eritroderma terbanyak dengan usia >60, Faktor Penyebab eritroderma tertinggi ialah Perluasan penyakit, Penatalaksanaan paling banyak yang diberikan kepada pasien eritroderma ialah kortikosteroid oral + pelembab + antihistamin.
\end{abstract}

Kata kunci : Eritroderma, Profil, Eritema, Kulit

\begin{abstract}
Erythroderma is an inflammation of the skin that affects $90 \%$ or more of the skin surface area, and can be accompanied by squama. Several case reports found the incidence of erythroderma in men is greater than in women, with cases 2:1 to 4:1, and an average age of 41-61 years. Erythrodermic therapy must be adapted to the conditions of the disease. The mortality rate depends on the cause of erythroderma. Due to the lack of research data on erythroderma, researchers want to see more of the characteristics of the disease. Objectives To determine the profile of Erythroderma patients at Pertamina Bintang Amin Hospital in the period 2 January 2016 - 31 December 2019. Method This study used an observational descriptive method with a retrospective design, sampling with total sampling. Results This study showed that the highest incidence of erythroderma occurred in 2016 many as 11 people (50.0\%). The majority of erythrodermic patients were male many as 13 people (59.1\%). Erythrodermic patients >60 years of age occupy the highest position in the age distribution many as 14 people (63.6\%). The highest cause of erythroderma was the expansion of the disease by 11 people (50.0\%). Management mostly given to erythrodermic patients was oral corticosteroids + moisturizers + antihistamines as many as 12 people (54.5\%).Conclusion: Highest incidence in 2016, Erythrodermic patients $>60$ years of age occupy the highest, The majority of erythrodermic patients were male, cause of erythroderma was the expansion of

the disease, Management mostly given to erythrodermic patients was oral corticosteroids + moisturizers + antihistamines.
\end{abstract}

Keywords: Erythroderma, Profile, Erythema, Skin

* Korespondensi Author : M. Ridho Noverliansyah,, Universitas Malahayati, lian.md96@gmail.com4 


\section{PENDAHULUAN}

Eritroderma merupakan inflamasi pada kulit yang mengenai $90 \%$ atau lebih luas permukaan kulit, dan dapat disertai dengan skuama. Pada beberapa penderita eritroderma, manifestasi skuama tidak selalu ditemukan, misalnya pada kasus eritroderma yang diakibatkan oleh alergi obat sistemik. Pada eritroderma proses kronik, eritema tidak begitu terlihat jelas, karena bercampur dengan hiperpigmentasi. Nama lain penyakit ini adalah dermatitis eksfoliativa generalisata, meskipun memiliki pengertian yang berbeda, Kata 'eksfoliasi' berarti pengelupasan pada skuama walaupun terkadang tidak begitu terlihat dan kata 'dermatitis' berdasarkan pada reaksi eksematosanya. ${ }^{1}$

Berdasarkan pengelompokan nya, eritroderma merupakan penyakit sekunder pada kulit yang termasuk dalam kelompok papulosquamous eruption, Beberapa kasus juga berhubungan dengan terjadinya erosi kulit kehilangan bagian epidermis dengan dasar epidermal), pengerasan kulit dan dapat berpotensi terjadi perubahan pada rambut dan kuku. Gangguan kulit ini, juga dapat timbul sebagai perluasan dari penyakit kulit yang telah ada sebelumnya (dermatitis atopik, psoriasis atau dermatosis spongiotik lainnya) pada reaksi hipersensitivitas obat (antibiotik, antiepilepsi, antihipertensi, calcium channel blocker, dan obat topikal) kemudian penyakit sistemik keganasan, dan penyakit idiopatik. ${ }^{2}$

Proses terjadi nya eritroderma tergantung penyakit yang mendasarinya. Kadar imunoglobulin E (IgE) yang tinggi dapat ditemukan pada eritroderma dan setiap tipenya memiliki kadar yang berbeda-beda. Dalam teori tingginya kadar IgE pada penderita eritroderma akibat penyakit psoriasis mungkin dapat disebabkan karena reaksi imunologi perubahan T-helper-1 (Th1) menjadi T-helper-2 (Th2) dan memproduksi sitokin yang bersifat toksik. Mekanisme lain juga bisa terjadi karena adanya produksi primer dari IgE pada penyakit dermatitis atopik. HyperIgE syndrome dikaitkan dengan terjadinya eritroderma dan berhubungan dengan reaksi/alergi, yang disebabkan proses produksi IgE meningkat dan mengsekresi interferon- $\gamma$ secara berlebihan. ${ }^{3}$

Istilah eritroderma digunakan untuk setiap inflamasi pada penyakit kulit yang mempengaruhi permukaan tubuh secara luas. Pada sebuah penelitian berasal dari Belanda memperkirakan kasus eritroderma setiap tahunnya 0,9 per 100.000 penduduk. Angka kematian berjumlah $16 \%$ dan biasanya terkait dengan imunodefisiensi. Di Indonesia, penelitian yang pernah dilakukan menunjukan angka kejadian eritroderma di RSUD Dr. Soetomo pada tahun 2005-2007 sebanyak 30 orang. ${ }^{3}$

Jumlah kasus sejak 1 Januari 2013-1 Januari 2017 di Poliklinik Dermatologi dan Venereologi RSUP dr. Sardjito didapatkan 10 pasien dengan diagnosis CTCL. Diagnosis eritroderma karena CTCL ditegakkan berdasarkan anamnesis, manifestasi klinis dan pemeriksaan laboratorium serta pemeriksaan histopatologis. Pada beberapa laporan kasus, insidensi eritroderma pada pria lebih besar daripada wanita, dengan jumlah kasus 2:1 sampai 4:1, pada usia 41-61 tahun. Angka kematian tergantung pada penyebab terjadinya eritroderma. Sigurdson melaporkan dari 102 pasien eritroderma didapatkan $43 \%$ kematian, $18 \%$ disebabkan langsung oleh eritroderma dan $74 \%$ tidak berhubungan langsung dengan eritroderma. ${ }^{1}$

Penanganan eritroderma di rumah sakit sangat penting, terutama pada fase akut dan kasus berat, disebabkan kondisi pasien mungkin dapat berubah menjadi lebih serius. Pada kasus eritroderma, keseimbangan asupan protein dan cairan elektrolit, sirkulasi, dan temperatur harus dijaga. Suhu lingkungan harus diatur secara hatihati. Keadaan suhu yang dingin harus dihindari dengan menggunakan selimut agar tetap hangat. Pengobatan eritroderma disesuaikan dengan penyakit yang mendasari, sehingga tidak semua kasus eritroderma dapat diberikan terapi spesifik yang sama. ${ }^{3}$

\section{METODE}

Penelitian ini menggunakan metode studi observasional deskriptif dengan pendekatan retrospektif. Observasional deskriprif 
merupakan metode yang digunakan untuk mengobservasi suatu data yang telah ada. Metode ini digunakan untuk mengevaluasi gambaran umum dari eritroderma Rumah Sakit Pertamina Bintang Amin Bandar lampung Populasi yang di gunakan adalah pasien sebanyak 22 orang dengan diagnosis klinis eritroderma. Penelitian sesuai dengan kriteria inklusi dan eklusi. Pertimbangan tentang populasi pada pasien dengan diagnosis eritroderma memiliki gambaran umum termasuk insidensi, penyebab, usia, jenis kelamin serta penatalaksanaan penyakit tersebut dan dapat dievaluasi.

\section{HASIL DAN PEMBAHASAN}

Selama periode 2 Januari 2016 - 31 Desember 2019 terdapat 22 pasien dengan diagnosis Eritroderma di Rumah Sakit Pertamina Bintang Amin. Adapun data yang dikumpulkan merupakan data dari rekam medis pasien Kulit dan kelamin yang tersusun dalam tabel distribusi sebagai berikut.

Tabel 1. Distribusi Frekueni Insidensi pasien eritroderma

\begin{tabular}{ccc}
\hline Insidensi & Frekuensi & Persentase \% \\
\hline 2016 & 11 & $50,0 \%$ \\
2017 & 5 & $22,7 \%$ \\
2018 & 3 & $13,6 \%$ \\
2019 & 3 & $13,6 \%$ \\
\hline Total & 22 & $100 \%$ \\
\hline
\end{tabular}

Berdasarkan tabel di atas terdapat 22 pasien eritroderma, pada tahun 2016 merupakan insidensi tertinggi dimana terdapat 11 pasien (50,0\%), di ikuti tahun 2017 berjumlah 5 pasien $(22,7 \%)$, tahun 2018 berjumlah 3 pasien $(13,6 \%)$ dan sama pada tahun 2019 berjumlah 3 pasien $(13,6 \%)$.

Tabel 2. Distribusi Frekuensi Usia pada pasien eritroderma

\begin{tabular}{lcc}
\hline Usia & Frekuensi & Persentase \% \\
\hline $5-14$ tH & 2 & $9,1 \%$ \\
$15-30$ th & 3 & $13,6 \%$ \\
$31-60$ th & 3 & $13,6 \%$
\end{tabular}

\begin{tabular}{lcc}
\hline Usia & Frekuensi & Persentase \% \\
\hline$>60$ th & 14 & $63,6 \%$ \\
\hline Total & $\mathbf{2 2}$ & $\mathbf{1 0 0}$ \\
\hline
\end{tabular}

Berdasarkan tabel di atas diketahui bahwa usia penderita eritroderma tertinggi yaitu usia dewasa $>60$ tahun $(63,6 \%)$. Sementara kejadian terendah pada usia anak 5-14 tahun $(9,1 \%)$, diikuti usia 15 - 30 tahun dan usia 31 60 tahun dengan persentase yang sama $(13,6 \%)$.

Tabel 3. Distribusi Jenis Kelamin pada pasien eritroderma

\begin{tabular}{lcc}
\hline Jenis & frekuensi & Persentase \% \\
Kelamin & & \\
\hline Laki -Laki & 13 & $59,1 \%$ \\
Perempuan & 9 & $40,9 \%$ \\
\hline Total & 22 & 100 \\
\hline
\end{tabular}

Berdasarkan tabel di atas diketahui bahwa penderita eritroderma tertinggi pada pasien dengan jenis kelamin laki-laki $(59,1 \%)$, dibandingkan pada pasien dengan jenis kelamin perempuan yaitu $(40,9 \%)$.

Tabel 4. Distribusi Faktor Penyebab terjadinya eritroderma

\begin{tabular}{lcc}
\hline Faktor Penyebab & Frekuensi & Persentase \% \\
\hline Reaksi Obat & 4 & $18,2 \%$ \\
Perluasan Penyakit & 11 & $50,0 \%$ \\
Idiopatik & & \\
Keganasan & 7 & $31,8 \%$ \\
& 0 & 0 \\
\hline Total & 22 & $100 \%$ \\
\hline
\end{tabular}

Berdasarkan tabel di atas diketahui bahwa penyebab eritroderma tertinggi yaitu disebabkan oleh perlusan penyakit sebelumnya $(50,0 \%)$ dan terendah disebabkan oleh reaksi hipersenitivitas obat $(18,2 \%)$.

Tabel. 5. Distribusi Frekuensi Penatalaksanaan eritroderma

\begin{tabular}{lcc}
\hline Penatalaksanaan & Frekuensi & Persentase \% \\
\hline $\begin{array}{l}\text { kortikosteroid } \text { oral }+ \\
\text { pelembab }+\end{array}$ & 12 & $54,5 \%$
\end{tabular}




\begin{tabular}{lcc}
\hline Penatalaksanaan & Frekuensi & Persentase \% \\
\hline $\begin{array}{l}\text { antihistamin } \\
\text { kortikosteroid injeksi } \\
+ \text { antihistamin }\end{array}$ & 3 & $13,6 \%$ \\
$\begin{array}{l}\text { kortikosteroid oral + } \\
\text { pelembab + } \\
\text { antihistamin + }\end{array}$ & 4 & $18,2 \%$ \\
$\begin{array}{l}\text { Antibiotik } \\
\text { kortikosteroid topikal } \\
+ \text { metotreksat }+\end{array}$ & 3 & $13,6 \%$ \\
pelembab & & \\
\hline Total & 22 & 100 \\
\hline
\end{tabular}

Berdasarkan tabel di atas diketahui bahwa penatalaksanaan farmakologi eritroderma tertinggi dengan menggunakan kombinasi Kortikosteroid oral + pelembab + antihistamin $(54,5 \%)$. Pada penggunaan terendah yaitu kombinasi Kortikosteroid Topikal + metotreksat + pelembab dan kombinasi kortikosteroid injeksi + antihistamin $(13,6 \%)$.

Berdasarkan hasil penelitian insidensi eritroderma di Rumah Sakit Pertamina Bintang Amin Bandar Lampung terdapat 22 orang pasien dengan diagnosis eritroderma. Pada tahun 2016 merupakan insidensi tertinggi dimana terdapat 11 orang $(50,0 \%)$, diikuti tahun 2017 terdapat 5 orang $(22,7 \%)$, tahun 2018 terdapat 3 orang $(13,6 \%)$ dan sama pada tahun 2019 terdapat 3 orang $(13,6 \%)$. Hasil penelitian ini relatif lebih rendah jika dibandingkan hasil penelitian Nanda Earlia,dkk di RSUD dr.Soetomo Surabaya yaitu sebanyak 30 kasus eritroderma. Hasil penelitian ini juga lebih rendah pada penelitian yang dilakukan oleh Anugerah,dkk di RSUP. Mohammad husein palembang dimana terdapat 52 kasus eritroderma. Perbedaan hasil bisa terjadi karena penelitian dilakukan di rumah sakit berbeda dimana terdapat perbedaan jumlah populasi dan jumlah sample dari penelitian yang lain. ${ }^{4}$

Berdasarkan usia penderita eritroderma didapatkan data tertinggi yaitu usia $>60$ tahun sebanyak 14 orang $(63,6 \%)$. Diikuti usia $15-31$ tahun sebanyak 3 orang $(13,6 \%)$ dan 31-60 tahun sebanyak 3 orang $(13,6 \%)$. Hasil penelitian ini berbeda dengan penelitian
M.Mochtar,dkk di RSUD Dr. Moewardi Solo didapatkan terbanyak pada kelompok umur 3160 tahun, yaitu 25 pasien $(64,10 \%)$ dan yang paling sedikit kelompok umur 5-14 tahun $(5,12 \%)$. Hasil penelitian ini juga sesuai dengan kepustakaan Fitzpatrick yang mengatakan insidensi tersering pada rata-rata usia 41-61 tahun atau kelompok usia dekade 6. Pada anak usia 5-14 tahun adalah kelompok pasien eritroderma paling sedikit 2 orang $(9,1 \%)$, hal tersebut juga sesuai dengan kepustakaan bahwa eritroderma lebih jarang muncul pada anak, prevalensinya diperkirakan 0.1 persen dari populasi pasien dermatologi anak. ${ }^{4,6}$

Berdasarkan jenis kelamin penderita eritroderma, didapatkan jenis kelamin laki-laki lebih tinggi 13 orang $(59,1 \%)$ dibandingkan jenis kelamin perempuan sebanyak 9 orang $(40,9 \%)$. Hasil ini sejalan dengan penelitian Anugerah,dkk di RSUP Mohammad Husein palembang didapatkan pasien eritroderma yang terbanyak pada laki-laki yaitu $51,92 \%$ (27 pasien) sedangkan pada perempuan 48,08\% (25 pasien). Penelitian Nanda Earlia,dkk Di RSUD dr. Soetomo Surabaya, kasus eritroderma paling banyak ditemukan pada laki-laki yaitu 63,3\% (19 pasien) dan pada wanita didapatkan sebanyak 36,7\% (11 Pasien). Hasil ini juga sejalan dengan penelitian Javeria Hafeez di RS Militer Rawalpin ditemukan terbanyak pada laki laki yaitu $70 \%$ dan pada perempuan yaitu $30 \%$. Hal yang sama disebutkan dalam berbagai kepustakaan seperti Fitzpatrick yang menyebutkan bahwa eritroderma lebih banyak pada laki laki dari pada perempuan dengan perbandingan $2: 1$ sampai $4: 1^{4,5}$

Berdasarkan penelitian diketahui penyebab eritroderma pada pasien di rumah sakit Pertamina Bintang Amin tahun 2016 sampai 2019, dengan kasus tertinggi disebabkan perluasan penyakit sebelumnya sebanyak 11 orang $(50,0 \%)$. Sementara dari data penyebab terendah yaitu reaksi obat 4 orang $(18,2 \%)$ dan diikuti idiopatik sebanyak 7 orang $(31,8 \%)$. Pada kasus idiopatik kemerahan muncul di permukaan kulit dan disertai rasa gatal, pasien tidak memiliki riwayat penyakit kulit, serta riwayat mengkonsumsi obat atau alergi terhadap 
obat-obatan. Pada kasus dengan penyebab reaksi obat pasien memiliki riwayat mengkonsumsi obat antibiotik. Pada kasus perluasan penyakit didapatkan pasien eritroderma dengan penyakit iktiosis vulgaris, dermatitis atopik, psoriasis vulgaris dan pemphigus vulgaris. Pada beberapa kasus eritroderma disertai infeksi sekunder. Selain itu pada eritroderma akibat penyakit keganasan tidak ditemukan.

Pada kepustakaan Fitzpatrick, eritroderma dibagi menjadi 4 kelompok yaitu sebagian besar kasus didahului oleh perluasan penyakit kulit seperti dermatitis spongiotik (20-24\%), atopik $9 \%$, dermatitis kontak $6 \%$, dermatitis seboroik $4 \%$, dermatitis aktinik kronis 3\%, psoriasis (23\%), reaksi hipersensitivitas obat (15\%), keganasan Cutaneous T-Cell Lymphoma CTCL (16\%) dan Idiopatik (20\%). Dari kepustakaan Rook dan Wilkinson pada tabel klasifikasi menyebutkan penyebab tersering adalah tipe eksema dan variasinya (40\%), psoriasis (25\%), obat (10\%), CTCL dan leukemia (15\%) dan Idiopatik (8\%). Kepustakaan di atas sejalan dengan hasil penelitian, dengan penyebab tersering adalah perluasan penyakit. Perbedaan etiologi dapat terjadi karena : 1. Letak geografis suatu daerah 2. Jumlah sampel berbeda 3. Eritroderma akut cukup sulit untuk menentukan penyakit dasarnya, dan banyak kemiripan pada beberapa penyakit kulit, memungkinkan kesalahan dapat terjadi. ${ }^{6,7,8}$

Berdasarkan penelitian diketahui penatalaksanaan farmakologi eritroderma tertinggi dengan menggunakan kombinasi kortikosteroid oral + pelembab + antihistamin 12 orang $(54,5 \%)$, diikuti kortikosteroid oral + pelembab + antihistamin + Antibiotik 4 orang $(18,2 \%)$. Tatalaksana terendah pada kombinasi kortikosteroid injeksi + antihistamin 3 orang $(13,6 \%)$ dan kortikosteroid topikal + metotreksat + pelembab 3 orang $(13,6 \%)$. Terapi kortikosteroid oral dan injeksi yang paling sering digunakan yaitu metilprednisolon, untuk kortikosteroid topikal seperti clobetasol propional dan antibiotik oral yang digunakan yaitu levofloxacin, cefotaxim. Antihistamin oral yang paling sering digunakan ialah loratadin, sementara pada cream pelembab dengan komposisi urea $10 \%$ yang paling banyak digunakan.

Pada penelitian yang dilakukan oleh Mochtar dkk. di RSUD Dr. Moewardi Solo pemberian terapi sistemik kortikosteroid yang digunakan adalah metilprednisolon dan dexametasone, namun metilprednisolon lebih sering digunakan karena efek samping lebih sedikit. Penyembuhan terjadi cepat, umumnya dalam beberapa hari hingga beberapa minggu. Berdasarkan kepustakaan fitzpatrick, inflamasi pada kulit harus segera diterapi misalnya dengan menggunakan cream pelembab/emolien ataupun kortikosteroid. Pada penderita eritroderma dengan penyakit dasar psoriasis dapat dipertimbangkan pemberian metotreksat. Antibiotika sistemik dapat diberikan jika terdapat tanda-tanda infeksi sekunder. Antihistamin dapat juga diberikan untuk mengurangi pruritus dan memberi efek sedasi, sehingga pasien dapat tidur nyenyak di malam hari dan mengurangi ekskoriasi akibat garukan. ${ }^{6}$

\section{KESIMPULAN DAN SARAN}

Berdasarkan penelitian yang telah dilakukan di Rumah Sakit Pertamina Bintang Amin pada periode 2 Januari 2016 - 31 Desember 2019 untuk mengetahui insidensi, usia, jenis kelamin, faktor penyebab serta penatalaksanaan yang di berikan pada pasien eritroderma, dapat ditarik kesimpulan sebagai berikut : Insidensi eritroderma tertinggi terjadi pada tahun 2016, Mayoritas pasien eritroderma di Rumah Sakit Pertamina Bintang amin dengan Jenis Kelamin laki-laki, Pasien eritroderma dengan usia >60 tahun menempati posisi tertinggi. Faktor Penyebab eritroderma tertinggi pada penelitian ini ialah Perluasan penyakit. Penatalaksanaan paling banyak yang diberikan kepada pasien eritroderma ialah kortikosteroid oral + pelembab + antihistamin.

Kepada peneliti selanjutnya Dilakukan penelitian yang lebih mendalam seperti hubungan salah satu karakterisitik tersebut dengan kejadian eritroderma. Dilakukan edukasi kepada masyarakat tentang eritroderma dan kepada tenaga kesehatan untuk lebih dalam lagi mengetahui tentang penyakit eritroderma. 


\section{UCAPAN TERIMAKASIH}

Saya ucapakan terimakasih banyak kepada para dosen pembimbing serta penguji yang telah memberikan waktunya untuk membimbing saya dalam penulisan skripsi ini, tak lupa saya ucapkan terimakasih kepada orang tua dan saudara, serta teman teman yang selalu memberikan doa dan dukungan.

\section{REFERENSI}

1. Hari Purwanto, Sri Awalia F, Kristiana Etnawati. Eritroderma karena cutaneous T-cell lymphoma (CTCL),MDVI. 2018:45(4):193-197.

2. Rasmi Zaskia Oktarlina, Devi Putri Amalia Suryani. Eritroderma et causa Alergi Obat, Jurnal Fakultas Kedokteran Universitas Lampung,2017:6(2):98-102.

3. Shelma Maharani, Trisniartami Setyaningrum The Profile of Erythroderma Patients, Berkala Ilmu Kesehatan Kulit dan Kelamin - Periodical of Dermatology and Venereology, 2017:29(1):4451.

4. Anugerah DS, Athuf $\mathrm{T}$, Muhammad I H P. Angka kejadian dan faktor penyebab eritroderma di poliklinik ilmu kesehatan kulit dan kelamin RSUP Dr.Mohammad Hoesin Palembang Periode 2009-2011. MKS.2015;1(2):79-83.

5. Jane Margaret Grant-Kels, Flavia Fedeles, Marti J. Rothe. Exfoliative dermatitis. Fitzpatrick's dermatology in general medicine. $8^{\text {th }}$ ed. New York: The McGraw-Hill Companies: 2012.

6. Moerbono Mochtar ,Syntia Sari T, Sakti Charlia M ,Leonardo Trinarizki ,Angka kejadian eritroderma di RSUD Dr. Moewardi Surakarta, MDVI, 2015: 42(4):12 - 16.

7. Silverberg JI. Public Health Burden and Epidemiology of Atopic Dermatitis. Dermatol Clin. 2017;35(3):283-289.

8. Tan GF, Kong YL, Tan AS, Tey HL. Causes and features of erythroderma. Ann Acad Med Singap.2014;43(8):391-4. 